\title{
The hydrological linkage of mountains and plains in the arid region of northwest China
}

\author{
QIN Jia ${ }^{1 *}$, DING YongJian ${ }^{1} \&$ YANG GuoJing ${ }^{2}$ \\ ${ }^{1}$ State Key Laboratory of Cryospheric Sciences, Cold and Arid Regions Environmental and Engineering Research Institute, Chinese Academy of \\ Sciences, Lanzhou 730000, China; \\ ${ }^{2}$ Cold and Arid Regions Environmental and Engineering Research Institute, Chinese Academy of Sciences, Lanzhou 730000, China
}

Received November 18, 2012; accepted January 21, 2013; published online April 12, 2013

\begin{abstract}
Mountain regions supply a large amount of fresh water for the people in arid and semiarid regions, however, there is great uncertainty of the water quantification from mountains to lower areas. In order to assess the hydrological significance of mountains and the hydrological linkage of mountains and plains, the measured and simulated hydrological data of the arid region in northwest China were used in the present research which followed a catchment-based approach. Firstly, the Heihe River Basin, a welldocumented area, was selected as a specific watershed to reveal the hydrological relationship between highlands (mountains) and lowlands (plains); and then, the significance and disproportion of mountain runoff of 8 river basins as cases in the arid region of northwest China were analyzed and compared following the above analysis. The results of the study showed that the proportion of mountain runoff in total basinal runoff (PMR) of most rivers is above 50\%. The PMR are between 50\%-95\% in the rivers originated in the northern slope of the Tianshan Mountains where the aqueous vapor is relatively sufficient. And that, almost all the flow of the rivers originating from the Qilian Mountains, the southern slope of the Tianshan Mountains, and the northern slope of the Kunlun Mountains come from mountain regions. Also the PMR gradually increases from west to east in northwest China. The hydrological significance and disproportion of mountains water in the arid region of northwest China were given a systematic and thorough assessment, and the results could give potential guides for the scientific utilization of water resources in these regional areas for relieving the more and more serious shortage of water resources due to climate warming and population expansion.
\end{abstract}

water balance, mountain runoff, hydrological significance of mountains, hydrological linkage, arid region of northwest China

Citation: Qin J, Ding Y J, Yang G J. The hydrological linkage of mountains and plains in the arid region of northwest China. Chin Sci Bull, 2013, 58: 3140-3147, doi: $10.1007 / \mathrm{s} 11434-013-5768-4$

Mountain, an important water-source region, can effectively supply water resources to its neighboring lower hills and plains. Not only abundant rainfall, there are also a large number of glaciers and snow storage in the high-altitude mountains. The melting water from glacier makes up large amount of water resources. Most rivers on the Earth have their sources in mountain regions. The relationship between mountains and plains in water balance is an important scientific problem. There were many researches about that and had a lot of results, especially in the glaciology and clima-

*Corresponding author (email: qinjia418@163.com) tology [1-8]. Though the existing researches have actively promoted the development of mountain hydrology and the studies in water balance linkage of mountains and plains, there are still many contradictions and problems needed to be solved, such as the shortage of the systematic researches and quantificational describes about hydrological significance of mountains.

The arid region of northwest China, located in the hinterland of the Eurasia, covers approximately $24.5 \%$ of China's total land area, and about $43.5 \%$ of it are mountains and hills [9-11]. Little precipitation with vast evaporation makes there become one of the world's most severe drought 
areas. Water consumed in northwest China mainly relies on the discharge of the inland rivers originating from mountains. Precipitation and melting water which are built up in mountains supply fresh water for the people living in arid regions. It is essential and meaningful to quantify the contribution of water from mountains to lower areas. Though the quantification of hydrological significance of mountains has already been analyzed in some typical regions worldwide [12], relative researches in northwest China are still staying at the qualitative stage with the quantification remains uncertain.

In the present research, simulated data were used to cover the shortage of meteorological and hydrological measured data in mountains. The aim of this research is to better understand the hydrological relationship between highlands (mountains) and lowlands (plains) and to systematically and quantificationally assess the hydrological significance of mountains in the arid region of northwest China. The present research follows a catchment-based approach. Relative analyses had been employed in a typical watershed and then, following the findings, the hydrological significance of mountains in several different river basins of the arid region in northwest China were investigated and compared. In addition, this paper proposed a new index to indicate the hydrological significance of mountains.

\section{Hydrological significance of mountains in the specific watershed}

\subsection{Description of typical watershed}

The Heihe River is the second largest inland river in China, providing the most important water resource for the Hexi Corridor region, which originates from the Qilian Mountains, and disappears in Juyan Lake Basin. The Heihe River Basin lies between $98^{\circ}-101^{\circ} 30^{\prime} \mathrm{E}$ and $38^{\circ}-42^{\circ} \mathrm{N}$. The average temperature in plains of the study area is $2.8-7.6^{\circ} \mathrm{C}$, and annual precipitation is from 50 to $250 \mathrm{~mm}$; precipitation in mountains lying in the south of the study area is relative abundant, and its annual value is from 250 to $500 \mathrm{~mm}$. Compared with other places in the arid region of northwestern China, there are more dense observation network of hydrological and meteorological data and more abundant the measured data in the Heihe River Basin. Eleven hydrological stations and 8 meteorological stations are located in the upper and middle reaches of the Heihe River (above Zhengyixia hydrological station), and the measured data in these stations have better accuracy and long-time sequence, so we chose the upper and middle reaches of the Heihe River as the typical study area for the further analysis (Figure 1).

\subsection{Materials and methods}

In the present research, water balance components in mountains and plains were analyzed to preliminarily reflect the hydrological significance of mountains. In order to obtain more accurate values of the water balance components and the spatial distributions in the upper and middle reaches of the Heihe River, the whole study area was divided into small watersheds based on the software of ArcGIS 9.2. Water balance of the study area can be analyzed in different elevations by calculating the water balance of each small watershed. The water balance components of the study area including the regional precipitation $(P)$, runoff $(R)$, evaporation $(E)$ and water storage changes $(\Delta S)$. The water balance relationship can be expressed as

$$
P=R+E+\Delta S \text {. }
$$

Precipitation data were mainly obtained from national meteorological stations and some hydrological stations in the study area. As meteorological stations in high-altitude mountains are few, in order to compensate the shortage of observed precipitation in mountains, assimilated precipitation data which got from APHRODITE in Japan (http:// www.chikyu.ac.jp/precip/) were applied for analysis. Interpolation method was used to calculate precipitation in each grid cell (5 min). Runoff and evapotranspiration data were calculated by the VIC (Variable Infiltration Capacity) model, which was widely used and got very satisfactory results in northwest China $[13,14]$. The VIC model could simulate components of water balance in each grid cell $(5 \mathrm{~min})$ of the study area, based on which temporal and spatial water balance, such as the water balance change with elevations in the study area can be calculated. Simulated results can be compared with existing measured data in observation sites of the study area to test the accuracy of the simulations. After optimizing the parameters, the calibrated VIC model which has satisfied simulated results in the typical watershed [15] was used to analyze hydrological significance in mountains. All data input in the VIC model were converted to the suitable file style model needed. Observed and simulated data in the research were all in the period 1997-2005.

\subsection{Relationship between mountains and plains in water balance in the Heihe watershed}

The study area is composed of high-altitude mountains and low-altitude plains, while it is difficult to distinguish mountains and lowlands because there is no applicable definition of mountains on a global scale at present [16]. For the present study, a pragmatic approach was taken to solve the problem. The mean altitude of most existing hydrological stations, which were used to separate upstream and downstream of watersheds in the study region, was selected as the borderline of the mountains and plains. Regions above that altitude are considered as mountains, while others are plains. There are many upstream hydrological stations and they lie from southeast to northwest in the Heihe River Basin. Most of them stand near $2000 \mathrm{~m}$ contour, so the borderline between mountains and plains in the Heihe River Basin 


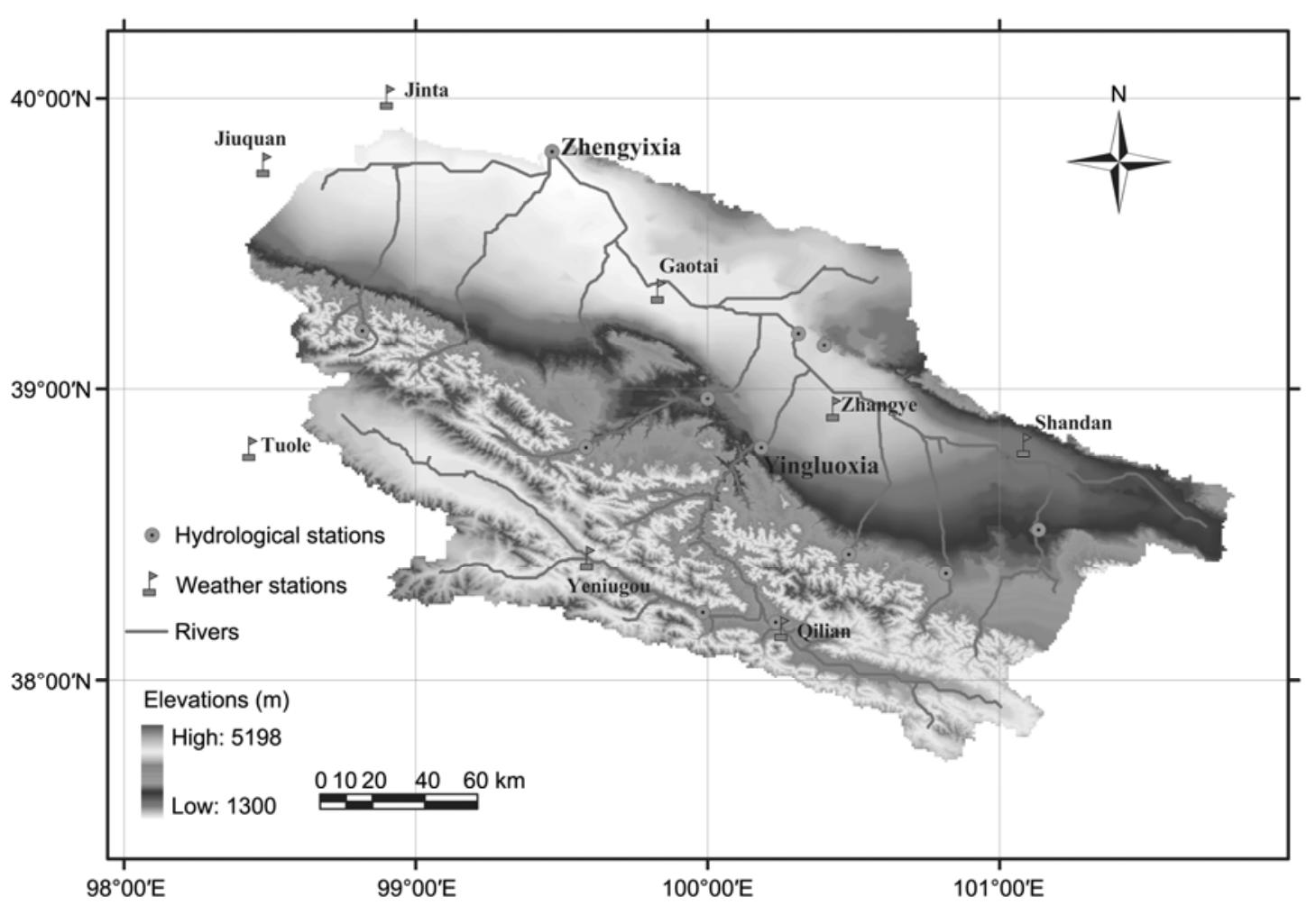

Figure 1 Hydrological and weather stations in the study area.

was set at $2000 \mathrm{~m}$ a.s.l.

Figure 2 shows the multi-year distributions of different water balance components in each sub-watershed of the specific study area over the period 1997-2005. It can be seen that precipitation, evapotranspiration and runoff respectively in mountains are higher than those in low-altitude plains; though groundwater reserve in some plains have been risen also, their increasing quantity is fewer than that in mountains. Higher altitude, more increased groundwater there in unit area. According to distributions of runoff and water storage changes in Figure 2, we concluded that water productivity and water resources in mountains are significantly higher than that in low-altitude plains.

Based on the distributions of water balance components in each small basin in Figure 2, area-weighted method was used to calculate each water balance component in mountains, plains and the whole areas of the upper and middle reaches of the Heihe River basin respectively (Table 1). On the whole, in unit area, precipitation and runoff in mountains were significantly higher than those in plains, also the runoff productivity. More than half of the study area is covered by mountains, and most of the water resources in the study area are produced there. However, runoff productivity is different in different mountain areas. Figure 3 shows the proportional changes of the area, precipitation and runoff at different altitudes in the study area. In the high-altitude regions, proportions of runoff are significantly higher than that of area in the same height with the proportion of the area, because precipitation become more as the altitude higher. For example, precipitation and runoff at altitudes of $4000-4500 \mathrm{~m}$ a.s.l. account for $34 \%$ and $17 \%$ of the total in the study area respectively, while the area at altitudes of $4000-4500 \mathrm{~m}$ a.s.l. accounts for only $11 \%$ of the total. In comparison, precipitation and runoff at altitudes of 1500$2000 \mathrm{~m}$ a.s.l. account for $12 \%$ and $4 \%$ respectively, but the area there accounts for almost $22 \%$ of the total of the study area. This further confirms the importance of mountain water resources in arid areas.

The figures analyzed above inferred that a spatially differentiated description of the water balance verify and underline the hydrological significance of mountain regions in the Heihe River Basin. The subsequent chapter will highlight the importance of the alpine region for this water supply of the lowlands, and further expand the research scope to analyze the issue of the hydrological significance of mountains within the arid region of northwest China.

\section{Hydrological linkages of highlands and lowlands}

\subsection{Hydrological significance of the Qilian Mountains}

The West Pacific subtropical high and the westerly winds have significant impact on the Qilian Mountains. A great deal of water vapor reaches here, and produces large mountainous precipitation, which accumulate and form mountain 

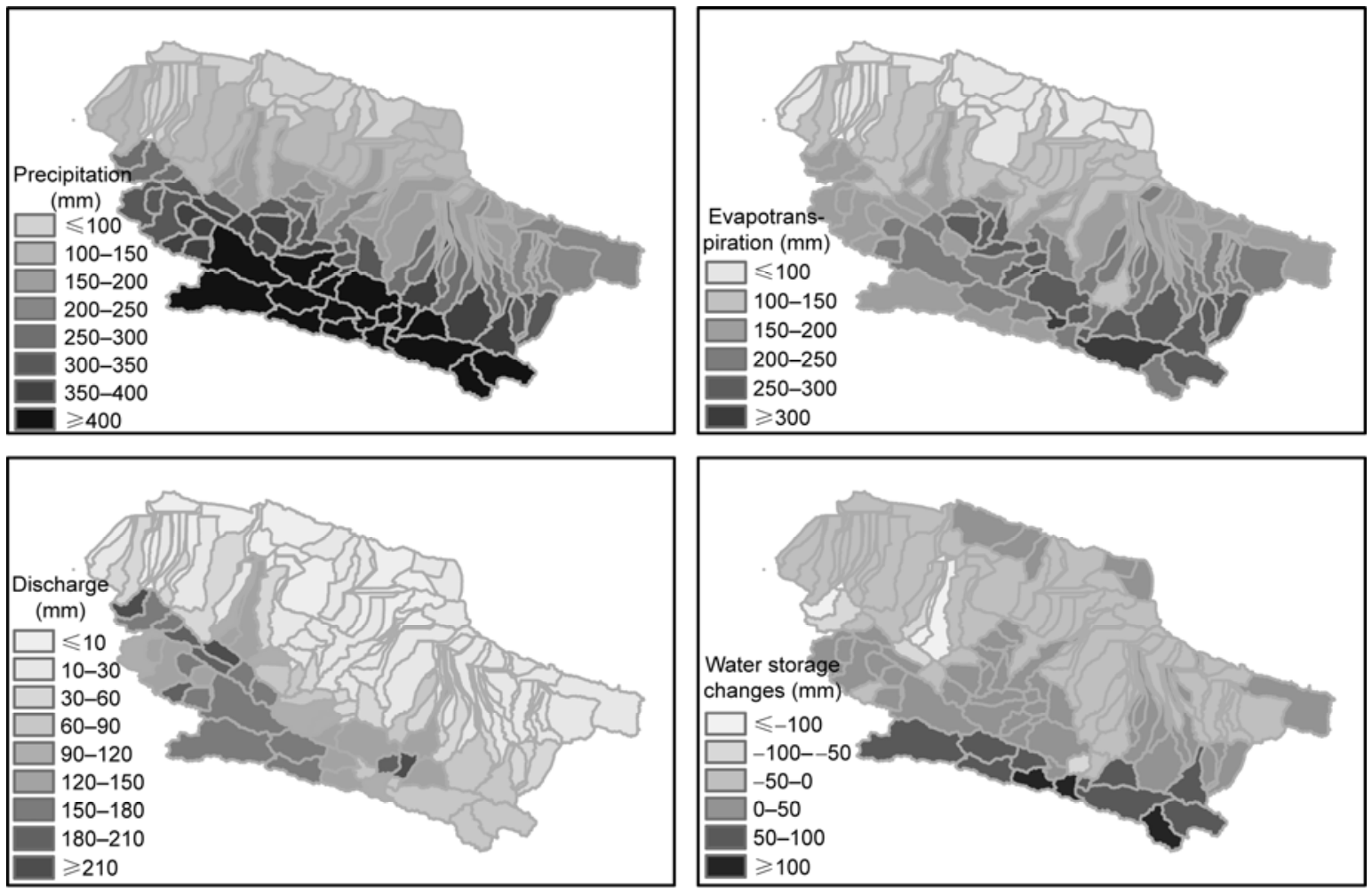

Figure 2 Annual distributions of water balance components in each sub-watershed in the study area.

Table 1 Annual distributions of water balance components in the study area during the period 1997-2005

\begin{tabular}{lcccc}
\hline & Precipitation $(\mathrm{mm})$ & Runoff $(\mathrm{mm})$ & Evapotranspiration $(\mathrm{mm})$ & Changes of water storage $(\mathrm{mm})$ \\
\hline Mountains & 387.3 & 152.9 & 214.7 & 19.7 \\
Plains & 172.3 & 20.1 & 136.3 & 15.9 \\
The whole study area & 232.7 & 63.5 & 161.9 & 7.3 \\
\hline
\end{tabular}

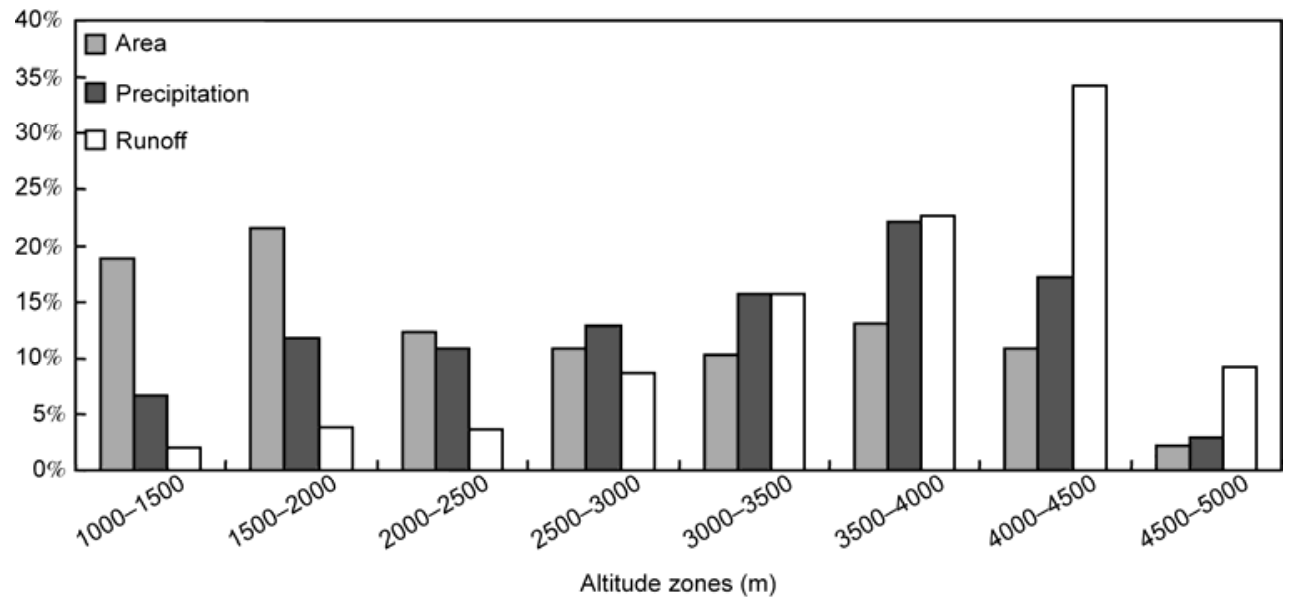

Figure 3 Proportion of watershed area, precipitation and runoff respectively in different elevations in the study area.

runoff, then flow out the mountains and supply the downstream water resources. In addition, alpine glacier water and snow melt water are also important runoff component. Melt water can provide a lot of runoff to reduce the runoff varia- bility, and make the runoff in lowlands more stable.

There are three major watersheds in the Qilian Mountains: Shiyang River, Heihe River and Shule River Basin. Shiyang River Basin, with $3.72 \times 10^{8} \mathrm{~m}^{3}$ annual runoff in 
average (observed in Xiangjiawan hydrological station), runoff from mountains in the basin is $13.97 \times 10^{8} \mathrm{~m}^{3}$, and accounting for $375.7 \%$ of the basin total runoff, while the mountainous area is only $7667 \mathrm{~km}^{2}$ which accounts for $54.5 \%$ of the total area in the Shiyang River Basin (the total area refers to the basin area controlled by Xiangjiawan hydrological station). The Heihe River Basin (above Zhengyixia hydrological station) has the total area of $35634 \mathrm{~km}^{2}, 47.6 \%$ of which are mountainous area $\left(16978 \mathrm{~km}^{2}\right)$. The annual total runoff of the Heihe River Basin is $10.5 \times 10^{8} \mathrm{~m}^{3}$ (observed in Zhengyixia hydrological station), and the mountain runoff is $20.9 \times 10^{8} \mathrm{~m}^{3}$ which contributes $198.7 \%$ of total basin runoff. The limited area of the Qilian mountain contributes quantity of stream flow, and most water resources consumed in plains are supplied by runoff generated in mountains.

Figure 4 shows the monthly changing processes of the total runoff and mountain runoff in the Heihe River Basin. Precipitation in winter half year is little in the whole basin, no matter plains or mountains, while the total area of the Heihe River Basin was much larger than the mountain area in the basin, and the result in the total runoff was significantly greater than the mountain runoff in that period. In summer half year, mountain runoff was significantly greater than the total runoff. With temperatures rising from March to May, the mountain runoff was increasing gradually (Figure 4) and snow melt runoff in spring supplies the discharge in Heihe River effectively. With the arrival of rainy season and the recharge of the glacier melt water, the mountain runoff had the largest value in summer compared with the other seasons in a year. As shown in Figure 4, from April to September, runoff from mountains was much larger than the basin total runoff. Little water was produced and almost no runoff is formed in this period in the lowlands, limited precipitation was consumed by evaporation. The basin water resources depend mainly on the mountain precipitation and glacier snow melt water supplies. The water reduced after it flow out of the mountains because of irrigation, production and living consumption in plains, and finally reached to the Zhengyixia hydrological station. Figure 5 shows the specific discharges (discharge per square kilometers per second) along the course of the Heihe River Basin. The specific discharges in summer half year were higher than that in winter half year, with the water production in summer half year was larger. No matter in summer half year, winter half year or the whole year, specific discharge decreases gradually from upstream to downstream of the Heihe River Basin. Water production gradually enhanced from the lowlands to the highlands. These illustrated that the Qilian Mountain was the main water production region in the Heihe River Basin, and most water resources of arid inland river basin were originate from mountains.

\subsection{Hydrological significance of mountains in the arid region of northwest China}

We selected a few representative basins, which distribute in different regions of northwestern China, to systematically study the hydrological effects of mountains. Table 2 lists the hydrological stations of some main rivers in northwest China, with corresponding drainage area of mountains and plains controlled by these stations. Because of the different geographical characteristics and climate in each watershed, all of the selected river basins were divided into three groups. The first group rivers (Group 1) which originated in the northern slope of Tien shan (Chinese for "Celestial Mountains") included the Tekes River, Kashi River, Toutun River and Manas River; the second group (Group 2) originating from the southern slope of the Tien Shan and the northern slope of the Kunlun Mountains contained the Weigan River and Hotan River; and the third group rivers (Group 3) was consisted of the Heihe River and Shiyang River which originated from the Qilian Mountains.

We divided the mountain runoff (observed in the mountain

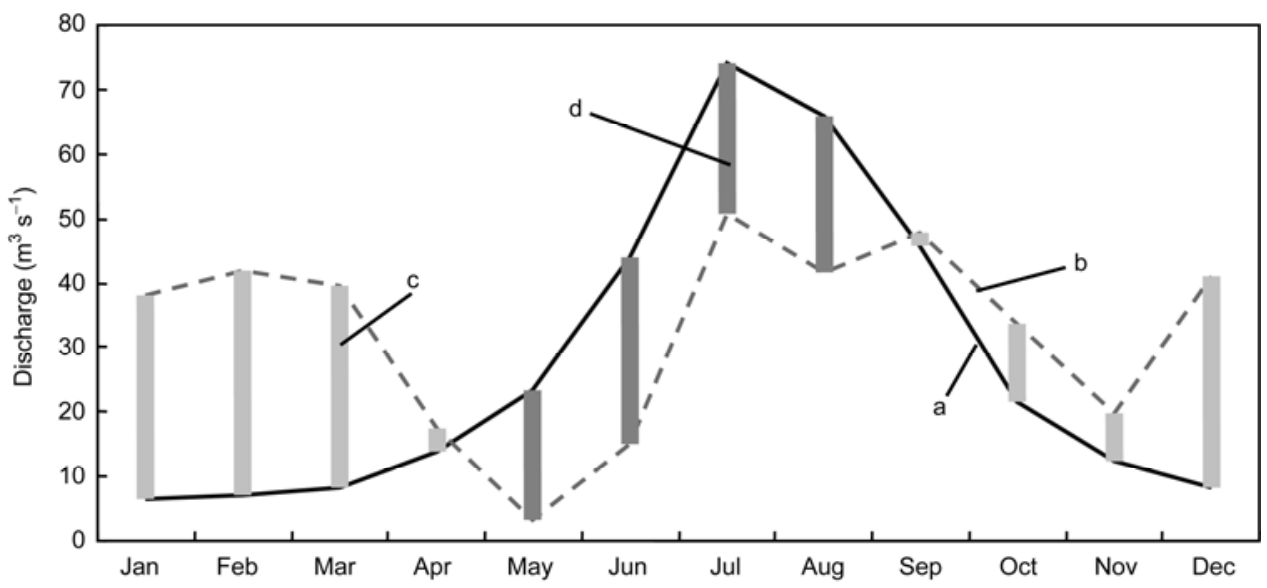

Figure 4 Monthly discharges of mountains (a) and the whole watershed (b) in the specific study area; (c) contributions of discharge in plains to total discharges, (d) water consumptions of plains. 


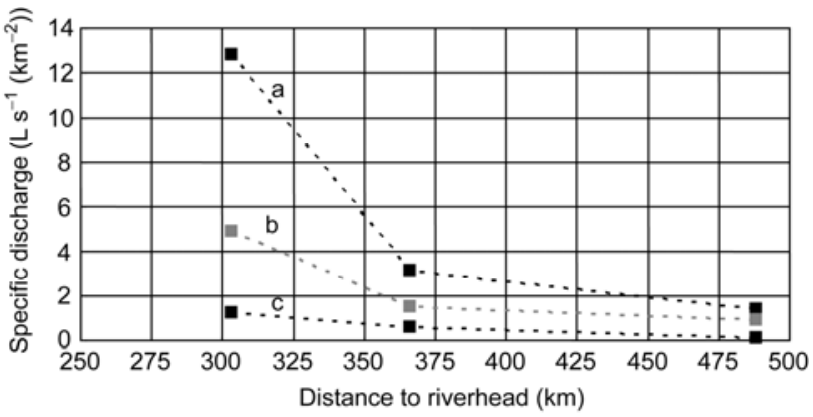

Figure 5 Specific discharge changes from highlands to lowlands in the Heihe River watershed. a, Specific discharge in summer half year; $b$, specific discharge changes all year around; $c$, specific discharge in winter half year.

hydrological stations) by the total runoff (observed in the hydrological station of the middle reaches of each river) to indicate the mountain proportion of total runoff (PMR) in each river basin. The relationships between mountain runoff and runoff in plains in different regions of northwestern China were analyzed to figure out the contribution of mountain runoff. As could be seen from Figure 6, PMR was generally higher than $50 \%$ of each river basin and most runoff of each watershed came from mountains. The effect of mountains as "water tower" is very significant. Though the PMR in rivers of Group 1 were all lower than 100\%, mountain runoff exceeded the total basinal runoff in one month at least. It illustrated that the supply of mountain runoff to water in lowland or plains was significant during the dry season; in Groups 2 and 3, the total basinal runoff was less than mountain runoff in each river and the proportions of mountain runoff were all larger than $100 \%$, and the main reason was that the irrigation water in plains consumed large amount of channel flow which came from mountains. Mountain runoff for each watershed of Groups 2 and 3 were greater than runoff in plains in most months, compensation of mountain runoff to downstream plains had more significant effect. Water resources in the arid region of northwest China are mainly supplied by mountain runoff.
In order to assess the importance of the runoff compensation effect, the percentage of mountain area in each river basin (PMA) was calculated in the paper (Figure 6). The PMA was got through dividing mountain area by total basin area controlled by hydrological station in the middle reaches of each river. The PMA mostly ranges from $50 \%$ to $70 \%$ in river basins of the arid region, northwest China, except for the Manas River. We proposed mountain runoff disequilibrium index (MDI), which was the value of the PMR divided by the PMA of each river, to indicate the hydrological significance of mountains. Table 3 shows the MDI value of each representative basin in the research. The MDI value equal to 1 means that PMR and PMA are equal, and this will happen in theory. MDI value greater than 1 indicates that the actual mountain runoff is larger than the theoretical runoff correspond to its mountain area of the river basin, and means runoff in mountain is larger than that in plains in the watershed. According to Table 3, runoff capacity of mountains in the upper reaches is generally higher compared to that of plains in river basins, northwest China.

In addition, there exists spatial difference in mountain runoff. The PMR is different from east to west of the arid region of northwestern China, the same in the north-south direction. The PMR is gradually increasing from west to east, with the PMR value increasing from 53.7\% (Turks River stays in the most western) to $375.7 \%$ (Shiyang River exists in the most eastern); the PMR values of river basins in Group 1 which exist in the north of the arid region are smaller than those of Weigan River and Hotan River Basins in Group 2 which stay in the southern part. The MDI values of river basins in Groups 2 and 3 are larger than those in Group 1 and means that the contribution of water from mountains to basin in Groups 2 and 3 is higher than that in Group 1. Precipitation in river basins of Group 1 is relatively more abundant compared with that in Groups 2 and 3, difference of precipitation in mountains and precipitation in plains is smaller in Group 1 than that in Groups 2 and 3. This is the main reason why contribution rates of mountain runoff in river basins of Group 1 is smaller than those of

Table 2 River basins with measuring hydrological stations in the arid region of northwest China: mountains (1) and plains (2)

\begin{tabular}{|c|c|c|}
\hline River & Hydrological station & Catchment area $\left(\mathrm{km}^{2}\right)$ \\
\hline \multirow{2}{*}{ Tekes River } & (1) Jiefangdaqiao, Kukesu & 13914 \\
\hline & (2) Qiapuqihai & 27402 \\
\hline \multirow{2}{*}{ Kashi River } & (1) Wulasitai & 5081 \\
\hline & (2) Tuohai & 8656 \\
\hline \multirow{2}{*}{ Toutun River } & (1) Zhicaichang & 840 \\
\hline & (2) Hadipo & 1562 \\
\hline \multirow{2}{*}{ Manas River } & (1) Kensiwate & 4637 \\
\hline & (2) Hongshanzui & 5156 \\
\hline \multirow{2}{*}{ Weigan River } & (1) Ahabulong, Kamuluke, Kalasu, Heizi & 9149 \\
\hline & (2) Qianfodong & 16637 \\
\hline \multirow{2}{*}{ Hotan River } & (1) Tongkezileke, Wuluwati & 34558 \\
\hline & (2) Xiaota & 48870 \\
\hline \multirow{2}{*}{ Heihe River } & (1) Yingluoxia, Liyuanhe, Lijiaqiao, Shuangshusi, Wafangcheng, Fenglehe & 16978 \\
\hline & (2) Zhengyixia & 35624 \\
\hline \multirow{2}{*}{ Shiyang River } & (1) Zamusi, Sigouzui, Shagousi, Chajianmen, Nanyinshuiku, Huangyangshuiku, Gulangshuiku & 7667 \\
\hline & (2) Xiangjiawan & 14071 \\
\hline
\end{tabular}




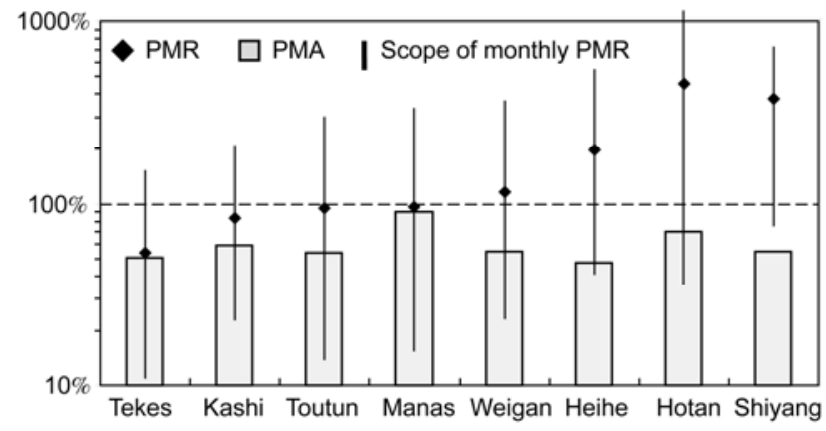

Figure 6 The mean annual mountain proportion of total runoff (PMR) and proportion of total area (PMA) in different watershed in the arid region of northwest China.

Table 3 Mountain runoff disequilibrium index (MDI) of different watersheds in the arid region of northwest China

\begin{tabular}{ccccccccc}
\hline & Tekes & Kashi & Toutun & Manas & Weigan & Heihe & Hotan & Shiyang \\
\hline MDI & 1.1 & 1.4 & 1.7 & 1.1 & 2.1 & 4.2 & 6.4 & 6.9 \\
\hline
\end{tabular}

\section{Groups 2 and 3.}

As there have differences in climate between mountains and plains, hydrological effects of mountains are significantly different with that of plains. Precipitation and temperature are two major climatic factors affecting the runoff and have large difference in mountains and plains. Compared with plains, mountains have abundant precipitation, lower temperatures and lower evaporation rate, and it is easy to form runoff in mountains; because of the lower altitude, water vapor is difficult to uplift and it is difficult to form precipitation in arid plains, coupled with the high temperature and large evaporation, few runoff could be formed in these regions. In addition, there are water resources storage as ice and snow in mountains, in summer half year, ice and snow will melt and can effectively supply runoff in arid regions.

\section{Conclusions and discussions}

Because of special climate conditions, hydrological effect of mountains in the arid region of northwest China is quite significant. Though relative researches have focused on this theme, they were mainly limited to one or more specific river basin, and often lacked integrity and systematic $[17,18]$. One main problem that the hydrological researches of mountains still face is the great heterogeneity of the hydrological and meteorological factors [11,19]. Few observation stations in mountain regions lead to the shortage of meteorological and hydrological measured data and make the study of water balance in mountains meet great difficulties. To solve the problem, the present research attempt to use simulation method of the VIC model. The VIC model can effectively simulate the regional hydrological processes of northwestern China, especially in mountains which are very short of the hydrological observation data. As large coverage of glacier exists in the study area [20], a Glacier Melting Module was added to the VIC Model to simulate the compensation for runoff from glacial melting. Based on the improved VIC model, the research accurately simulated the changes of water balance components and analyzed the relationship of water balance between mountains and plains in the arid region of northwest China.

Mountains are wet islands and they play the role of "water towers" of the arid regions. Altitude difference results in the special climate in mountains. Snowmelt and precipitation build up there and form a large amount of discharge with which mountains supply people living in the arid areas. Compared with plains, mountains have abundant precipitation, lower temperatures and lower evaporation rate. Water production per unit area there is higher than that in plains. About $27650 \mathrm{~km}^{2}$ glacier covers in the arid region of northwest China [20]. Ice and snow melt water, in summer half year especially during the dry season, can effectively compensate water shortage in arid regions.

In order to analyze the compensation effects of mountain discharge, the present research propose a new index (PMR) to represent the hydrological significance of mountains. The proportion of discharge contributed by mountains varies from $50 \%$ to $95 \%$ according to the arid region, with extreme figures of $100 \%$. The hydrological significance of mountains varies in different regions of northwest China due to the difference of climate and population distribution characters. The arid region of northwest China can be divided into three parts overall: the Junggar Basin and the mountains around where river basins in Group 1 mainly distribute; the Tarim Basin and the surrounding mountain where river basins in Group 2 mainly distribute; the Hexi Corridor region and the surrounding mountain where river basins in Group 3 mainly distribute. Compared to the other two regions, PMR in Junggar Basin and the surrounding mountain was significantly lower, the main reason may be the sparse population and low water consumption in lowlands there; in the other two regions there are a large number of water consumption for agricultural irrigation and municipal water in the middle and lower reaches of watershed, resulting in a high PMR. Except to it, precipitation in the Junggar Basin is larger than that in the Tarim Basin and the Hexi Corridor region, while the compensation rates of glacier and snow melting water in the basins which stay in the Tarim Basin are larger than those in the basins of the Junggar Basin. Higher precipitation in lowlands and smaller compensation rates of melting water perhaps are also the reasons why PMR in Junggar Basin and the surrounding mountain was significantly lower than the other two regions. Mountain vegetation characters, which effect the evapotranspiration, water conservation and water distributions, vary in different regions of northwest China and this may result in different hydrological significance of mountains. 
Nearly half of the areas in arid northwest China are mountains, and these mountains have been playing an important role in water storage and supply. With global climate warming and population explosion, water resources in mountains are facing a severe test. The rise of temperature cause glaciers retreat dramatically [21-23]. In the coming short period, the contribution of glacier melt water to basinal runoff perhaps will increase, but in the long run, the compensation capacity of melt water is bound to gradually reduce . In addition, with climate change, the regional rainfall and snowfall will change in the future no matter in space, time, volume or precipitation variability. This will directly result in water resource changes of mountains. Hydrological significance of mountains will changed relatively and perhaps the differences of MDI will smaller in different regions of northwest China as the global warming. In consideration of the limited water in mountains, the water resource should be scientifically and rationally distributed and utilized, and all of the water use in industry, agriculture and animal husbandry and climate change should be taken into account. The expansion of population is bound to increase the water consumption in plains where most people are living in. The water resource in mountains will be under greater pressure. Population pressure will seriously affect water resources eventually and this problem needs to be paid enough attention. In the future, water resources issue is no longer just a research problem in the earth system processes, the long-term effects of human activities, such as dams, inter-basin water transfer, extensive irrigation, also should be considered. How to scientifically and rationally manage water resources is very important and necessary in the water-deficient regions.

Our study mainly analyzed the distribution of discharge and other hydrological components in mountains and plains. Further study of the influence of irrigation and other human activities on water resources was not detailed in the present research. This aspect should be improved in the future research. In addition, as the shortage of observed data, analyses in our study were based on the limited basins. There is an urgent need to make data publicly and set more observed hydrological and meteorological stations in mountains so as to higher spatial resolution of relative study on water resources.

This work was supported by the National Natural Science Foundation of China (41130638 and 41271035) and the Knowledge Innovation Program of the Chinese Academy of Sciences (KZCX2-YW-QN310). The assistance of Ye Baisheng in the field is gratefully acknowledged.

1 Meybeck M, Green P, Vorosmarty C J. A new typology for mountains and other relief classes: An application to global continental water resources and population distribution. Mountain Res Dev, 2001,
21: 34-45

2 Messerli B, Viviroli D, Weingartner R. Mountains of the world: Vulnerable water towers for the 21 st century. Contribution to the Royal Colloquium on Mountain Areas, Abisko 2003. Ambio Spec Rep, 2004, 13: 29-34

3 Hanspeter L, John G, Boniface K, et al. Assessing and managing scarce tropical mountain water resources. Mountain Res Dev, 2005, 25: 163-173

4 Aeschbacher J, Liniger H P, Weingartner R. River water shortage in a highland-lowland system: A case study of the impacts of water abstraction in the Mount Kenya region. Mountain Res Dev, 2005, 25: 155-162

5 Liniger H P, Weingartner R, Grosjean M, et al. Mountains of the World: Water Towers for the 21st Century-A Contribution to Global Freshwater Management. Berne. Switzerland: Mountain Agenda, 1998

6 Shen Y P, Liu S Y, Zhen L L, et al. Fluctuations of glacier mass balance in watersheds of Qilian mountain and their impact on water resources of Hexi region (in Chinese). J Glaciol Geocryol, 2001, 23: 244-250

7 Ma H W, Wang N A. The response of runof of Shiyang River basin in Mountainfoot to climate change (in Chinese). J Arid Land Resour Environ, 2010, 24: 113-117

8 Wang N L, Zhang S B, He J Q, et al. Tracing the major source area of the mountainous runoff generation of the Heihe River in northwest China using stable isotope technique. Chin Sci Bull, 2009, 54: 2751-2757

9 Luo X X, Yang J Q. Researches on the questions and countermeasures of sustainable utilization of water resources in the northwest area of China (in Chinese). Areal Res Dev, 2003, 22: 73-76

10 Wang G X, Cheng G D, Xu Z M. The utilization of water resource and its influence on eco-environment in the northwest arid area of China (in Chinese). J Nat Resour, 1999, 14: 109-116

11 Liu J M, Ma Y G. Characteristics, protection and utilization of water resources in arid regions in northwest China (in Chinese). Agric Res Arid Areas, 1998, 16: 103-107

12 Daniel V, Rolf W. The hydrological significance of mountains: From regional to global scale. Hydrol Earth Syst Sci, 2004, 8: 1016-1029

13 Liu Z F, Xu Z X. Analysis of hydrological variables based on the VIC-3L model in head water catchment of the Tarim river basin (in Chinese). J Beijing Normal Univ, 2010, 46: 350-357

14 Zhao Q D, Ye B S, Ding Y J, et al. coupling a glacier melt model to the Variable Infiltration Capacity (VIC) model for hydrological modeling in north-western China. Environ Earth Sci, 2013, 68: 87-101

15 Qin J, Ding Y J, Wu J K, et al. Understanding the impact of mountain landscapes on water balance in the upper Heihe River watershed in northwestern China. J Arid Land, 2013 (in press)

16 Ives J D, Messerli B, Spiess E. Introduction. In: Messerli B, Ives J D, eds. Mountains of the World: A Global Priority. New York and London: Parthenon, 1997. 1-15

17 Chen C Y. Water resource on Qilian mountainous region and its influence on ecological environment of Hexi Corridor (in Chinese). J Nat Resour, 1995, 10: 104-114

18 Zhou Y C, Zhang G W. Mountain water balance of the Urumchi River and its total water resource (in Chinese). J China Hydrol, 1991, 6: 9-15

19 Tian R X, Gao L, Gao Y X. Spatial and temporal variation of annual rainfall in the northwest arid areas of China (in Chinese). Plateau Meteorol, 1995, 14: 90-95

20 Yang Z. Glacier Water Resources in China (in Chinese). Gansu, China: Gansu Science and Technology Press, 1990. 138-139

21 Li K M, Li Z Q, Gao W Y, et al. Recent glacial retreat and its effect on water resources in eastern Xinjiang. Chin Sci Bull, 2011, 56: 3596-3604

22 Duan K Q, Yao T D, Wang N L, et al. Numerical simulation of Urumqi Glacier No. 1 in the eastern Tianshan, central Asia from 2005 to 2070. Chin Sci Bull, 2012, 57: 4505-4509

23 Li X Y, Ding Y J, Ye B S, et al. Changes in physical features of Glacier No. 1 of the Tianshan Mountains in response to climate change. Chin Sci Bull, 2011, 56: 2820-2827

Open Access This article is distributed under the terms of the Creative Commons Attribution License which permits any use, distribution, and reproduction in any medium, provided the original author(s) and source are credited. 